\title{
Accountability Assessment of Tourism Awareness Group (Pokdarwis) from Governance Paradigm (Case Study of Pokdarwis Wonderful Sangiran Indonesia)
}

\author{
Titik Djumiarti \\ \{titi_artik@yahoo.co.id\} \\ Universitas Diponegoro, Indonesia
}

\begin{abstract}
The aim of the research is to identify and understand the accountability of tourism awareness group (Pokdarwis) Wonderful Sangiran, Indonesia with the governance paradigm. The research is qualitative using ethnography method for collecting data through participant observation. The research finding shows that accountability of tourism awareness group is manifested through several mechanisms, namely 1) the clarity of strategy, vision, mission, and objective of the organization; 2) the transparency of regulation status; 3 ) actuating organization chart on base program; and 4) improving democratic leadership pattern; and strengthening decision making mechanism and responsibility. That being said, Pokdarwis Wonderful Sangiran has shown accountability values such as trust, responsiveness, a healthy organizational climate, legality and public legitimacy, organizational clarity, rules and laws, and stakeholder and public acceptance. Therefore, this research leads to propose a preposition that in order to be accountable organization, Pokdarwis as non-governmental organization (NGO) can implement such mechanisms, namely clarifying guiding organizational philosophy, vision, mission and objective on the basis of the real social problems; legal status, structure, functions, and relations between structure-based focus of the work; strong leadership the ideology of civil society, networks, and togetherness; and the decision making mechanisms and accountability. Lastly, NGOs can use accountability values such as trust responsiveness, a good organizational environment, legality and government legitimacy, organizational clarity, governance and small stakeholders, and government recognition.
\end{abstract}

Keywords: Accountability, Governance Paradigm, Pokdarwis.

\section{Introduction}

The substance of the governance paradigm is the building of consensus between the government (state actor), the private sector (market) and the community (civil society) in the framework of synergizing various public affairs. This concept shows that governance has several important elements, namely multi-factor, consensus building, accommodation and synergy [1]. Actors in governance has to pass through the process of building a network of interactions through consensus to achieve synergy.

Accountability is a principle of governance that involves government, private sector, and community. It is expected that all actions taken by government, private sector, and community can be accountable to the public. An efficient accountability system can be carried out through government monitoring and public controlling. 
In the perspective of governance, public has power to control and monitor how the government works as they are expected to be transparent. In other words, government must be monitored by the non-state actors, such as mass media, interest groups, professional institutions, communities, and non-governmental organizations (NGOs).

The meaning of accountability is derived from the idea of a democratic society that is oriented towards accountability to external parties including social interaction, social change, and the right to authority [2]. However, in practice of governmental and non-governmental organizations, the substance of accountability has neglected many elements of society as the main actors.

Furthermore, the implementation of accountability theory is not yet optimal. It is still trapped in pseudo accountability which is oriented in the short term of performance achievements rather than changes in long-term impacts of social change or power sharing. It can be seen through the non-sustainable and not holistic programs and activities in nongovernmental organization which will be further explained as the case study of this research.

On top of that, there is a problem that arises in the context of accountability in NGO, namely what the accountability is actually for, what kind of accountability is, and how accountability is carried out. It is because generally the accountability authority is solely used in the government sector. Therefore, this research relies on the development of NGO by bringing up tourism awareness group (Kelompok Sadar Wisata/Pokdarwis) in Sangiran as the case study. This group is named as Pokdarwis Wonderful Sangiran which is located in Krikilan village, in Sangiran ancient human conservation area of Sragen Regency, Indonesia. Pokdarwis Wonderful Sangiran is an interesting NGO to be assessed their accountability due to the spirit of their establishment for synergizing the community and government interests, upholding the sustainability of Sangiran as a conservation area as well as creating positive impact in the economy through tourism development.

In its implementation, the existence of Pokdarwis in Sangiran conservation area has not run effectively. Pokdarwis organizational structure is not run consistently and sustainably. Although there are formal provisions for the existence of Pokdarwis, their activities have not been running optimally as they prefer enhancing collaboration with donor agencies and dealing with conservation issue to improving tourism side.

Thus, this research aims to identify and understand how the accountability of tourism awareness group (Pokdarwis) Sangiran, Indonesia.

\section{Literature Review}

\subsection{Governance}

The research uses a governance paradigm based on democratic values as stated by Rhodes [3], Kooimans [4], Piere and Peters [5] and Bovaird and Loffler [6]. According to Rhodes, governance is defined as self-organizing, international networks, and structure of network. Rhodes clearly shows the network as a key word for understanding the concept of governance [7].

Kooimans [8] further explains that governance is an interaction placed in the context of diversity, complexity, and dynamic of modern society. In modern society, the interaction between actors in a system is diverse and built network to one another. Interaction occurs in complex situations whose parts are vertically and horizontally interconnected and are related 
to the external environment. Interaction between actors and parts of the system with the environment occurs with dynamic intensity, such as tension, conflict, and synergy [8].

Other than that, Pierre and Peters [5] explains that governance as decision maker has to include various social actor and put government not as the only central actor. It means that the key dimensions of governance with regard to actors, processes, and results has to be public oriented (publicness).

The arguments of Bovaird and Loffler [6] explains the concept in understanding the governance paradigm, namely (1) Multi-stakeholders, cooperation in overcoming common interests (public interests); (2) Making agreements and complying formal and informal rules; (3) Not only paying attention to private sector structure but also hierarchical and network structures; (4) Not only prioritizing final result of social interaction process but also the character of actors; (5) Not depending on the ruling political elite but political authority is decentralized in central power that controls each other, including components of society that have equal access and empowerment [9].

That being said, interactions in governance are balanced, equal, and interdependent between state, market, and civil society. This interaction is built in such egalitarian way and does not dominate each other. The synergy between actors is established on the principles of participation, transparency, accountability, rule of law, responsiveness, consensus orientation, equity, and inclusiveness.

Accountability should be internalized within the institutions of government, private sector, and community actors including NGO in the context of building synergistic network interactions. The institutionalization of the principle of accountability will encourage the realization of governance, private good corporate governance, and community governance. The sense of governance highly requires strong accountability institutions from the actors, so that governance interaction can be achieved.

This research is conducted in the context of strengthening the institutional NGO as an important force in community. The assumption is that the development of NGO accountability is expected to encourage the community to have equal power with other actors. The fragile institutional NGO will also weaken community institutions and eventually imbalance in interactions that undermine governance buildings. Thus, in the sense of governance, it requires a strong degree of accountability from the actors in order to the interaction of governance is realized.

\subsection{Accountability}

The perspective of accountability governance is the interaction, interrelation, and mutual relations in openness and responsibility among NGOs and various components in society in the framework of controlling NGO decisions and actions to remain in accordance with the values, needs, and expectations of the community and its stakeholders.

Examining the issue of NGO accountability is closely related to the framework of governance theory as a network between government, private, and community. NGO as part of community is required to have public accountability. Accountability developed in the public sector and NGO is adopted from the theoretical framework and instruments in governance.

In understanding the substance of the concept of NGO accountability from the governance paradigm, this research firstly determines the concept of NGO. Non-governmental organization (NGO) is community-based organization which is formed on the basis of the community interests with the principles of being independent, voluntary, "non-profit", and 
local oriented. The type of its activities are development, empowerment, assistance, advocacy, and networking. Its member is community facilitators that are oriented towards strengthening and building public participation in the decision making process [10].

Therefore, NGO should be able to define the needs, interests, and expectations of the community. This can be seen from the programs and activities that are internalized through interaction between other governance actors, such as government and private sector with optimal network management.

\section{Methodology}

The research uses qualitative ethnography method by exposing the results of field research using data collection which is conducted through in-depth interviews by means of description, analysis, and in-depth exploration related to the reality and accountability process of non-governmental organization [11]. Taking tourism awareness group (Pokdarwis) Wonderful Sangiran, Indonesia as the case study, ethnographic method is considered pertinent to identify and understand the accountability of Pokdarwis Wonderful Sangiran through participant observation in Sangiran. It helps the researcher to see the changes of livelihood of Sangiran community in spite of only from historical story which is obtained by the observation of Pokdarwis Sangiran performance in daily basis and from the interview with neighborhood leaders and figures, Sangiran Museum administrator, and Head of Tourism, Culture, Youth and Sport Office of Sragen Regency.

The main focus of this research is the accountability of Pokdarwis Wonderful Sangiran which is related to its vision, mission, and objective, legal status, organizational structure, leadership and decision-making mechanisms and responsibilities.

\section{Discussion}

\subsection{Vision, Mission and Objectives of Tourism Awareness Group (Pokdarwis) Wonderful Sangiran}

Tourism Awareness Group (Pokdarwis) Wonderful Sangiran was formed and ratified on February 22, 2017 in Sragen Regency and chaired by Mr. Sadiman, well-known as Bapak Subur. This group, in accordance with Article 3 of its certified deed, aims to: (1) as a working partner of the Tourism, Culture, Youth and Sport Office of Sragen Regency in tourism marketing and tourism development activities in the Sragen Regency, especially in the Sangiran region; (2) having an active role in maintaining and developing tourism potential in Sragen Regency, especially in the Sangiran area of Sragen Regency; (3) carrying out organizational activities that promote togetherness, consensus agreement, and community welfare; (4) implementing Sapta Pesona in every activity; and creating the tourism-aware conditions in the Sangiran area by applying the principles of Sapta Pesona [12].

Besides, Pokdarwis Wonderful Sangiran has several missions, namely (1) to develop the tourism industry for creating employment and public welfare; (2) to increase the quality Sangiran's human resources, especially in terms of tourism; (3) to utilizing and exploring the potential of Sangiran natural resources in supporting tourism to be better in the future. 
In order to achieve these missions, Pokdarwis Wonderful Sangiran organizes the attractions or performances, creates attraction, promotes and preserves local arts and culture; and explores, elevates, and develops local products and potentials.

Since the establishment of Pokdarwis Wonderful Sangiran, there have been many activities carried out by Pokdarwis Wonderful Sangiran, including as: (1) implementing World Heritage Day celebrations on April 17, 2017; (2) conducting research collaborations with French MNHN at the Nano Pucung Museum and becoming a local guide in November 2017; (3) participating the Local Guide competency test held by the Education and Culture Office of Sragen Regency in March 2018; (4) joining the comparative study to Gamplong Sleman tourist village with Sangiran Ancient Human Site Management Agency; (5) taking part the technical guidance on homestay management from the Education and Culture Office of Central Java Province in April 2018; (6) taking part the technical guidance on homestay management at Surya Sujowati hotel and comparative study in Wonorejo tourism village in July 2018. For daily activities, Pokdarwis Wonderful Sangiran utilizes and manages a building established by the Sragen Regency Government known as the tower point of view [13].

\subsection{Clarity of the Legal Status of Tourism Awareness Group (Pokdarwis) Wonderful Sangiran}

Pokdarwis Wonderful Sangiran formed their legal status as NGO, a self-supporting group based on the strength of the village community with all its potential. Pokdarwis is built based on their potential because the community has the power to develop the village with all of their resources.

\subsection{Structure, Function, and Relations between Units in the Structure}

In general, the organizational structure of Pokdarwis Wonderful Sangiran consists of a board of directors with the chairperson of Bapak Subur. To ensure relations with governance, this organization combines elements of government, namely the Department of Youth and Tourism as a mechanism of control (check and balance), especially in development based on public interests.

Leadership in this group positions a central figure namely Bapak Subur, who established Pokdarwis and was assessed by the management and partners that he has the ideology and capacity to build networks to become leaders of an NGO.

\subsection{Decision Making and Accountability}

Decision making in the Pokdarwis Wonderful Sangiran, is still under the control of the Pokdarwis board of directors, especially in meetings with members. This shows that this NGO has control over sustainability and consistency and has authority in decision making. This principle is referred to as the governing body and is needed to develop the trust in the organization management.

The clarity of the existence of this group has implication in values such as professionalism, maintained the direction of the objective of organization, the trust of stakeholders, the conduciveness of organizational climate, and the effectiveness of the organizational management [14]. 


\subsection{Implementation of Tourism Awareness Group (Pokdarwis) Wonderful Sangiran in Sangiran Ancient Human Conservation Area}

The clarity of the existence of an organization is part of the essence of accountability, namely by taking actions that can be accounted for by various parties. As can be seen from the explanation of the vision, mission, and objective as well as the activities, the action of the Pokdarwis has a clear source of value, result of the study, work method status, and mechanism of accountability. Likewise, the clarity of existence can be seen from the relation with the problems, needs, and expectations of the community and the future direction of the organization.

In line with what was conveyed by Wyatt [8] that the basic documents from nongovernmental and governmental organizations are responsible institutions with the ownership of basic documents 1) self-guarding the mission; 2) setting values and standards; 3)ensuring resources and; 4) extending outreach. Edward and Hulme argued that the effectiveness of NGO accountability is marked by statements of organizational attributes in the form of vision, mission, goals and others [15].

The existence of legality or legal status explains that compliance with laws and other regulations is required as the use of public resources and is intended for public services or public interests. With a clear legal status, NGO has a clear role, undemanding process in administering agreements, and effortless access to programs and funds from the government and other donor agencies.

The clear legal status of NGO will be very important in order to maintain the existence and progress of institutions in the community. Clear legal status guarantees stakeholders not to hesitate to establish relationships while at the same time open access to access to resources, because building relationships with the government is always done legally.

The organizational structure shows the pattern of relationships between tasks and functions are well-integrated. There is a vertical relation which is a function of consultative, direction, and supervision. In this case, it is carried out by local governments, especially in synergizing with government programs. Horizontal relations are the function of coordination in internal management, and egalitarian relations on the basis of partnerships between the Pokdarwis management and the public or private. Wyatt stated that the types of relations in NGO structures can be hierarchical and aligned and the two types can also go along together.

The leadership of Pokdarwis Wonderful Sangiran is very dependent on the central figure who has been held by Bapak Subur up to now. Actually, the rules have been determined relating to the principles, mechanisms, and accountability of leadership. However, they are only a formal and conditional norm. In general, the method that can be done in the selection of leaders is through the election mechanism by members as it shows the implementation of democratic principles [16].

The decision-making process carried out by Pokdarwis Wonderful Sangiran is by consensus and voting. The dominance of the organization's board of directors has a central role in decision making. This is conducted in the context of maintaining consistency towards the public interests, especially the built-community. 


\section{Conclusion}

a) The accountability mechanism of a non-governmental organization can be identified by carrying out its vision, mission, and objective as a real foundation in accordance with the public interest; legal status; organizational structure that focuses on the commitment of organizational goals; strong leadership and a trust from civil society; and democratic decision making process that demonstrate trust, legal, and responsiveness.

b) In terms of the quality of the implementation of accountability, Pokdarwis Wonderful Sangiran still needs to be improved in order to be able to get closer to the essence of the principle of accountability, especially strengthening the organizational structure by establishing relations from elements of government, market, and civil society.

c) Reorganizing the mechanism for the selection of Pokdarwis membership by involving all actors, especially actors from the village officer.

\section{References}

[1] Pratikno, "Governance dan Krisis Teori Organisasi," J. Adm. dan Kebijak. Publik, vol. 11 No 2, N, p. 236, 2007.

[2] and E. W. Ebrahim, Alnor, "Global Accountability:Participation, Pluralism, and Public Ethics," New York: Cambridge University Press, 2007.

[3] R. A. W. Rhodes, "The new governance: governing without government," Polit. Stud., vol. 44, no. 4, pp. 652-667, 1996

[4] J. Kooiman, Modern governance: new government-society interactions. Sage, 1993.

[5] J. Pierre and B. Peters, Governing complex societies: Trajectories and scenarios. Springer, 2005.

[6] T. Bovaird, E. Löffler, and J. Martin, "From Corporate Governance to Local Governance: Stakeholder-Driven Community Score-Cards for UK Local Agencies?," Int. J. Public Adm., vol. 26, no. 8-9, pp. 1035-1058, 2003.

[7] N. Henry, Public Administration and Public Affairs. New Jersey : Pearson, 2004.

[8] Jon Kooimans. ed, Modern Governance: New Goverment - Society Interaction. Sage : London, 1993.

[9] Tony Bovaird and Elke Loffler, "evaluating the quality of Public Governance: Indicator, Models and Methodologie," Int. Rev. Adm. Sci., vol. Vol.69, no. SAGE Publication, 2003.

[10] D. Korten, Menuju Abad Ke-21: Tindakan Sukarela dan Agenda Global. Jakarta: Yayasan Obor, 2001.

[11] M. Hammersley and P. Atkinson, "The process of analysis," Ethnogr. Princ. Pract., pp. 158190, 2007.

[12] W. M. A. Therik and W. Handayani, "Penguatan Kapas," Pros. Semin. Nas. Has. Pengabdi. Kpd. Masy. Vol. 3 No. 1 Tahun 2018, vol. 3, no. 1, pp. 100-104, 2018.

[13] B. Sulistyanto, "Warisan dunia Situs Sangiran," Wacana, vol. 11, no. 1, pp. 57-80, 2009.

[14] C. Ansell and A. Gash, "Collaborative governance in theory and practice," J. Public Adm. Res. Theory, vol. 18, no. 4, pp. 543-571, 2008.

[15] M. and D. H. Edward, "Non Govermental Organizations," in NGO Performance and Accountability: Introduction and overview, London: Earthscan, 1995.

[16] E. Mulyantari, "Strategi Pengembangan Situs Manusia Purba Sangiran Sebagai Daya Tarik Wisata Budaya," J. Media Wisata, vol. 14, no. 1, pp. 333-344, 2016. 